\title{
Assessment of eating habits of patients qualified for bariatric surgery - preliminary research
}

\author{
Ocena zwyczajów żywieniowych chorych kwalifikowanych do zabiegu \\ bariatrycznego - badania wstępne
}

\author{
Edyta Suliga ${ }^{1}$, Kamila Sobaś ${ }^{1}$, Piotr Bryk ${ }^{2,3}$, Iwona Wawrzycka ${ }^{1,3}$, Stanisław Głuszek² \\ ${ }^{1}$ Institute of Health Sciences, Medical College, Jan Kochanowski University, Kielce, Poland \\ Head of the Institute: Edyta Suliga PhD, Prof. JKU \\ 2 Institute of Medical Sciences, Medical College, Jan Kochanowski University, Kielce, Poland \\ Head of the Institue: Beata Kręcisz MD, PhD, Prof. JKU \\ ${ }^{3}$ Clinic of General, Oncological, and Endocrinological Surgery, Provincial Hospital, Kielce, Poland \\ Head of the Clinic: Jacek Bicki MD, PhD
}

Key words: morbid obesity, bariatric surgery, dietary habits.

Słowa kluczowe: otyłość, operacje bariatryczne. nawyki żywieniowe.

\begin{abstract}
Introduction: Obesity, due to its prevalence, is considered an epidemic of the $21^{\text {st }}$ century and is characterized by the accumulation of excess body fat. The following are more common in people with obesity: coronary artery disease, hypertension, diabetes, dyslipidaemia, sleep apnoea, osteoarthritis, and neoplastic diseases. Current treatments have turned out to be ineffective, and the resulting weight loss is usually short-term. Bariatric surgery, combined with lifestyle changes in the form of modification of eating habits and increased physical activity, has been recognized as the most effective method of treating patients with morbid obesity

Aim of the research: To assess the eating habits and frequency of food intake of patients qualified for bariatric surgery.

Material and methods: The study was conducted among 48 patients with obesity staying at the Department of General, Oncological, and Endocrinological Surgery of the Provincial Polyclinic Hospital in Kielce, Poland. The study used the KomPAN questionnaire, developed by the Team of Behavioural Determinants of Nutrition of the Committee for Nutrition Research of the Polish Academy of Sciences.

Results: Almost $90 \%$ of patients scored low on the 'healthy diet index'. Only $12 \%$ of patients consumed wholemeal bread and/or thick groats every day. Additionally, $6 \%$ of the subjects drank milk every day, $4 \%$ fermented milk drinks, and $35 \%$ consumed cottage cheese several times a week. Similarly, most patients (including all people aged $>40$ years) scored low on the 'unhealthy diet index' (approx. 96\% of the group). Only 16.7\% of all patients had good nutritional knowledge, while $77.1 \%$ - regardless of the obesity class - had sufficient knowledge.

Conclusions: The low scores of the healthy diet index indicate the need for regular dietary consultations, during which patients will be educated about the use of nutritional knowledge and the application of healthy eating principles in practice.

\section{Streszczenie}

Wprowadzenie: Otyłość ze względu na jej rozpowszechnienie uważana jest za epidemię XXI wieku i charakteryzuje się gromadzeniem nadmiaru tkanki tłuszczowej. U osób otyłych częściej występują: choroba wieńcowa, nadciśnienie tętnicze, cukrzyca, dyslipidemia, bezdech senny, choroba zwyrodnieniowa stawów i choroby nowotworowe. Dotychczasowe programy terapeutyczne okazują się nieskuteczne w jej leczeniu, a uzyskana redukcja masy ciała najczęściej okazuje się krótkotrwała. Chirurgia bariatryczna, połączona ze zmianą stylu życia, została uznana za najskuteczniejszą metodę terapii chorych z otyłością olbrzymią.

Cel pracy: Ocena zwyczajów żywieniowych i częstości spożycia żywności przez chorych kwalifikowanych do zabiegu bariatrycznego.

Materiał i metody: Badania przeprowadzono wśród 48 chorych z otyłością przebywających w Klinice Chirurgii Ogólnej, Onkologicznej i Endokrynologicznej Wojewódzkiego Szpitala Zespolonego w Kielcach. W badaniach wykorzystano kwestionariusz KomPAN, opracowany przez Zespół Behawioralnych Uwarunkowań Żywienia Komitetu Nauki o Żywieniu Człowieka PAN.

Wyniki: Prawie 90\% chorych charakteryzowało się małym natężeniem cech odżywiania $\mathrm{z}$ „indeksu prozdrowotnej diety”. Tylko 12\% chorych codziennie spożywało razowe pieczywo i/lub grube kasze. Dodatkowo 6\% spośród badanych osób
\end{abstract}


codziennie piło mleko, $4 \%$ fermentowane napoje mleczne, a 35\% spożywało sery twarogowe kilka razy w tygodniu. Najliczniejsza grupa chorych (w tym wszystkie osoby w wieku > 40 lat) cechowała się małym natężeniem cech odżywiania $\mathrm{z}$,indeksu niezdrowej diety” (ok. 96\% próby). Jedynie 16.7\% badanych osób miało dobrą wiedzę żywieniową, natomiast $77.1 \%$ - niezależnie od klasy otyłości - wiedzę dostateczną.

Wnioski: Niskie natężenie indeksu prozdrowotnej diety wskazuje na potrzebę regularnych konsultacji dietetycznych, w czasie których chorzy będą edukowani na temat korzystania z informacji dotyczących żywności i stosowania zasad zdrowego żywienia w praktyce.

\section{Introduction}

Obesity, due to its prevalence, is considered an epidemic of the $21^{\text {st }}$ century and is a multifactorial, progressive, and lifelong disease characterized by the accumulation of excess body fat [1]. Morbid obesity is an extreme threat to the health and life of the patient, as well as posing a risk of premature death. People with obesity are more likely to suffer from coronary artery disease, arterial hypertension, diabetes, dyslipidaemia, sleep apnoea, osteoarthritis, and neoplastic diseases $[1,2]$. Diseases caused by obesity and overweight account for $25 \%$ of hospitalizations. The treatment of obesity as well as direct and indirect complications consumes $20 \%$ of the Polish health care budget (approximately PLN 67.5 billion) annually [3, 4]. The overall health care costs of overweight and obese people are as much as $44 \%$ higher than for people of normal weight. Current treatment programs have turned out to be ineffective, with the resulting weight loss most often turning out to be short-term [4].

Bariatric surgery has been recognized as the most effective method of treating patients with morbid obesity [5]. The following patients qualify for surgery: patients aged 18-65 years, with body mass index (BMI) $\geq 40 \mathrm{~kg} / \mathrm{m}^{2}$, as well as patients with BMI $35-40 \mathrm{~kg} / \mathrm{m}^{2}$ and coexisting diseases, in whom weight loss resulting from surgery may potentially aid in the treatment of the disease caused by obesity [5-7]. The reduction of body weight before surgery, which reduces the BMI below the values mentioned above, is not a contraindication to surgery [8]. The lack of documented attempts to reduce body weight before planned surgical treatment with conservative methods does not constitute a contraindication to the procedure in the group of adults. In morbidly obese patients over 65 years of age, qualification for bariatric surgery may also be considered [8]. The condition for starting treatment in this age group is the general health condition and biological age of the patient, which does not significantly increase the risk associated with surgical treatment $[5,8]$. In elderly patients, the benefits of surgery must outweigh the risks associated with surgery. It should be emphasized that bariatric surgery in this age group largely contributes to the improvement of the quality of life, while its effect on life extension and the reduction of severity of obesity-related diseases is much less important [9].

Research on the diet of people qualified for bariatric surgery, showing the dietary mistakes committed by them, is important due to the need to change the lifestyle of patients, even in the preoperative period. Weight loss before bariatric surgery may reduce the risk of complications in many patients and improve weight control after surgery [10].

\section{Aim of the research}

The aim of the study was to assess the eating habits and frequency of food intake of patients qualified for bariatric surgery.

\section{Material and methods}

The study was conducted among 48 patients with obesity, including 39 women and 9 men (mean age 43.2 and 42.7 years, respectively), treated at the Department of General, Oncological, and Endocrine Surgery of the Provincial Polyclinic Hospital in Kielce. The nutritional habits of people with obesity were analysed in 2 age groups, taking 40 years of age ( $<40$ and $\geq 40$ years) as the cut-off point. The research was carried out with the consent of the Bioethics Committee at the Collegium Medicum of Jan Kochanowski University in Kielce given on 26 March 2018 (approval number: 24/2018).

The average body weight of the studied patients was $123 \mathrm{~kg}(89-180 \mathrm{~kg}), 117 \mathrm{~kg}$ for women and $150 \mathrm{~kg}$ for men. The average height of the respondents was $167 \mathrm{~cm}$ for women and $178 \mathrm{~cm}$ for men. The degree of obesity was assessed based on the WHO criteria for the BMI index $\left(42.9 \pm 6.6 \mathrm{~kg} / \mathrm{m}^{2}\right)$ [11]: $59 \%$ of the respondents were people with class III obesity, $28 \%$ with class II obesity, and the remaining 13\% with class I obesity.

The study used the KomPAN questionnaire developed by the Team of Behavioural Determinants of Nutrition of the Committee for Nutrition Research of the Polish Academy of Sciences [12]. The questionnaire includes 4 parts: eating habits, frequency of food intake, views on food and nutrition, and lifestyle. Taking into account the frequency of the intake of foods and drinks, 2 indicators were calculated and used to assess the quality of the diet of people with obesity. The first of these indicators, the healthy diet index, consists of 11 food groups with potentially beneficial effects on health (wholemeal bread, milk, fermented milk drinks, cottage cheese, fish dishes, legumes, potatoes, fruit, vegetables, canned vegetables, or fruit juices). The second is the unhealthy diet index. It consists of 9 food groups with potentially adverse health effects (fast food, fried meat and flour-based dishes, hard and 
processed cheese, sweets and confectionery, instant soups and ready-made soups, canned meat, sweetened carbonated drinks, energy drinks, and alcoholic drinks). The indices were calculated by summing up the frequencies of intake, expressed as the number of times per day, and then converted to a 100-point scale. The results of the categories of frequency of consumption (ranks) and daily frequency (times/day) were as follows: never -0 ; $1-3$ times a month -0.06 ; once a week -0.14 ; several times a week -0.5 ; once a day - 1; (and several times a day. "pro-Healthy-DietIndex-10" (pHDI-10, in points $)=(100 / 20) \times$ sum of frequency of consumption of 10 food groups (multiples/ day). "non-Healthy-Diet-Index-14" (nHDI-14, in points) $=(100 / 28) \times$ sum of frequency of consumption of 14 food groups. On the basis of this scale, the range of healthy and unhealthy dietary habits was defined, and the evaluation of the score was as follows: low (0-25 points), moderate (26-75 points), or high (76-100 points). Nutritional knowledge was assessed on the basis of 25 statements about food and nutrition, for which the respondents gave a response of true or false [12]. If the answers were correct, they were assigned 1 point each, and then the sum of points was calculated, and the respondents were placed in 1 of the 3 groups: with insufficient (0-8 points), sufficient (9-16 points), or good (17-25 points) nutritional knowledge.

\section{Statistical analysis}

The statistical analysis was performed with the use of Statistica PL v. 10.0 by StatSoft. The consistency of the distribution of the examined features with the normal distribution was checked using the Kolmogorov-Smirnov test. The values of the features were expressed by the mean $(x)$ and median (Me) values, and their variability by standard deviation (SD). The feature distributions were compared with Pearson's $\chi^{2}$ test. In the statistical evaluation of the associations and the significance of the differences, the level of significance was $p \leq 0.05$.

\section{Results}

\section{Studies characteristics}

Most of the subjects were rural residents (35\% of the patients) while $27 \%$ of people lived in a city with more than 100,000 inhabitants (Table 1). Forty-eight per cent of the respondents had recieved higher education. The recommended number of 4-5 meals a day was consumed by $65 \%$ of patients, $33 \%$ of them ate meals irregularly, and $21 \%$ ate snacks between meals several times a day (Table 1). Among the foods consumed between meals, the patients most frequently declared consumption of fruit, sweet and salty snacks, seeds and nuts, and almonds (Table 2).

Table 3 shows the frequency of consumption of 11 food groups with potentially beneficial effects
Table 1. Characteristics of the subjects (\%)

\begin{tabular}{|c|c|c|}
\hline Characteristics & $\begin{array}{l}\text { Women } \\
n=39\end{array}$ & $\begin{array}{l}\text { Men } \\
n=9\end{array}$ \\
\hline \multicolumn{3}{|l|}{ Age [years]: } \\
\hline Mean \pm SD & $43.2 \pm 18.6$ & $42.7 \pm 4.9$ \\
\hline Median & 40.6 & 42.6 \\
\hline \multicolumn{3}{|l|}{ Age groups: } \\
\hline$<40$ years & \multicolumn{2}{|c|}{40} \\
\hline$\geq 40$ years & \multicolumn{2}{|c|}{60} \\
\hline \multicolumn{3}{|l|}{ Place of residence: } \\
\hline Rural & \multicolumn{2}{|c|}{35} \\
\hline Urban $<50,000$ residents & \multicolumn{2}{|c|}{25} \\
\hline $\begin{array}{l}\text { Urban } 50,000-100,000 \\
\text { residents }\end{array}$ & \multicolumn{2}{|c|}{13} \\
\hline Urban $>100,000$ residents & \multicolumn{2}{|c|}{27} \\
\hline \multicolumn{3}{|l|}{ Education: } \\
\hline Secondary & \multicolumn{2}{|c|}{31} \\
\hline Vocational & \multicolumn{2}{|c|}{21} \\
\hline Higher & \multicolumn{2}{|c|}{48} \\
\hline \multicolumn{3}{|l|}{$\begin{array}{l}\text { The frequency of } \\
\text { consumption of meals: }\end{array}$} \\
\hline 4-5 meals/day & \multicolumn{2}{|c|}{67} \\
\hline$\leq 3$ meals/day & \multicolumn{2}{|c|}{33} \\
\hline \multicolumn{3}{|l|}{$\begin{array}{l}\text { Among the food consumed } \\
\text { between meals: }\end{array}$} \\
\hline Several times a day & \multicolumn{2}{|c|}{21} \\
\hline One times a day & \multicolumn{2}{|c|}{27} \\
\hline Less than once a day & \multicolumn{2}{|c|}{52} \\
\hline
\end{tabular}

Table 2. Hierarchical list of food consumed between meals in descending order based on the answers provided by the subjects

\begin{tabular}{|lc|}
\hline Snacks between meals, \% of people* & \% of people* \\
Fruit & 71 \\
$\begin{array}{l}\text { Sweet snacks, e.g. sweets, cookies, cakes, } \\
\text { chocolate bars, muesli bars, wafers }\end{array}$ & 48 \\
$\begin{array}{l}\text { Seeds and nuts } \\
\text { Salty snacks such as crackers, salted } \\
\text { sticks, chips, French fries }\end{array}$ & 40 \\
$\begin{array}{l}\text { Vegetables } \\
\text { Milk, unsweetened milk drinks and milk } \\
\text { products, e.g. yoghurts, cottage cheese }\end{array}$ & 38 \\
$\begin{array}{l}\text { Sweetened dairy drinks and milk } \\
\text { products, e.g. creamed cheese spread, } \\
\text { sweetened milk drinks, flavoured milk }\end{array}$ & 27 \\
Other foods & 23 \\
\hline
\end{tabular}

*Subjects could choose any number of answers. 
Table 3. The frequency of intake of foods with a potentially beneficial effect on health, depending on the age of the patients

\begin{tabular}{|c|c|c|c|c|c|c|c|c|}
\hline \multirow[t]{2}{*}{ Product } & \multirow{2}{*}{$\begin{array}{c}\text { Age } \\
\text { category } \\
\text { [years] }\end{array}$} & \multicolumn{6}{|c|}{ Frequency of intake (\%) } & \multirow[t]{2}{*}{$P$-value } \\
\hline & & $\begin{array}{c}\text { No } \\
\text { consumption }\end{array}$ & $\begin{array}{l}1-3 \text { times } \\
\text { a week }\end{array}$ & $\begin{array}{c}\text { Once } \\
\text { a week }\end{array}$ & $\begin{array}{c}\text { A few } \\
\text { times } \\
\text { a week }\end{array}$ & $\begin{array}{l}\text { Every } \\
\text { day }\end{array}$ & $\begin{array}{l}\text { A few } \\
\text { times } \\
\text { a day }\end{array}$ & \\
\hline \multirow{3}{*}{$\begin{array}{l}\text { Wholemeal } \\
\text { bread }\end{array}$} & $<40$ & 0.0 & 36.8 & 10.5 & 36.8 & 5.3 & 10.5 & \multirow[t]{3}{*}{ NS } \\
\hline & $\geq 40$ & 6.9 & 10.3 & 6.9 & 55.2 & 10.3 & 10.3 & \\
\hline & Total & 4.2 & 20.8 & 8.3 & 47.9 & 8.3 & 10.4 & \\
\hline \multirow{3}{*}{$\begin{array}{l}\text { Buckwheat, } \\
\text { cereal, and } \\
\text { wholemeal } \\
\text { pasta }\end{array}$} & $<40$ & 0.0 & 47.4 & 10.5 & 42.1 & 0.0 & 0.0 & \multirow[t]{3}{*}{ NS } \\
\hline & $\geq 40$ & 13.8 & 27.6 & 24.1 & 27.6 & 3.5 & 3.5 & \\
\hline & Total & 8.3 & 35.4 & 18.8 & 33.3 & 2.1 & 2.1 & \\
\hline \multirow[t]{3}{*}{ Milk } & $<40$ & 10.5 & 26.3 & 5.3 & 31.6 & 21.1 & 5.3 & \multirow[t]{3}{*}{ NS } \\
\hline & $\geq 40$ & 17.2 & 24.1 & 24.1 & 13.8 & 13.8 & 6.9 & \\
\hline & Total & 14.6 & 25.0 & 16.7 & 20.8 & 16.7 & 6.3 & \\
\hline \multirow{3}{*}{$\begin{array}{l}\text { Fermented } \\
\text { milk drinks }\end{array}$} & $<40$ & 0.0 & 26.3 & 26.3 & 47.4 & 0.0 & 0.0 & \multirow[t]{3}{*}{ NS } \\
\hline & $\geq 40$ & 3.5 & 27.6 & 13.8 & 48.3 & 6.9 & 0.0 & \\
\hline & Total & 2.1 & 27.1 & 18.8 & 47.9 & 4.2 & 0.0 & \\
\hline \multirow{3}{*}{$\begin{array}{l}\text { Cottage } \\
\text { cheese }\end{array}$} & $<40$ & 0.0 & 42.1 & 21.1 & 36.8 & 0.0 & 0.0 & \multirow[t]{3}{*}{ NS } \\
\hline & $\geq 40$ & 3.5 & 27.6 & 34.5 & 34.5 & 0.0 & 0.0 & \\
\hline & Total & 2.1 & 33.3 & 29.2 & 35.4 & 0.0 & 0.0 & \\
\hline \multirow[t]{3}{*}{ Poultry } & $<40$ & 0.0 & 0.0 & 36.8 & 52.6 & 0.0 & 10.5 & \multirow[t]{3}{*}{$<0.05$} \\
\hline & $\geq 40$ & 0.0 & 10.3 & 13.8 & 69.0 & 6.9 & 0.0 & \\
\hline & Total & 0.0 & 6.3 & 22.9 & 62.5 & 4.2 & 4.2 & \\
\hline \multirow[t]{3}{*}{ Fish } & $<40$ & 10.5 & 31.6 & 31.6 & 21.1 & 5.3 & 0.0 & \multirow[t]{3}{*}{ NS } \\
\hline & $\geq 40$ & 0.0 & 27.6 & 58.6 & 13.8 & 0.0 & 0.0 & \\
\hline & Total & 4.2 & 29.2 & 47.9 & 16.7 & 2.1 & 0.0 & \\
\hline \multirow[t]{3}{*}{ Eggs } & $<40$ & 5.3 & 21.1 & 21.1 & 47.4 & 5.3 & 0.0 & \multirow[t]{3}{*}{ NS } \\
\hline & $\geq 40$ & 0.0 & 24.1 & 20.7 & 48.3 & 3.5 & 3.5 & \\
\hline & Total & 2.1 & 22.9 & 20.8 & 47.9 & 4.2 & 2.1 & \\
\hline \multirow[t]{3}{*}{ Legumes } & $<40$ & 15.8 & 79.0 & 0.0 & 5.3 & 0.0 & 0.0 & \multirow[t]{3}{*}{ NS } \\
\hline & $\geq 40$ & 6.9 & 72.4 & 17.2 & 3.5 & 0.0 & 0.0 & \\
\hline & Total & 10.4 & 75.0 & 10.4 & 4.2 & 0.0 & 0.0 & \\
\hline \multirow[t]{3}{*}{ Potatoes } & $<40$ & 5.3 & 26.3 & 15.8 & 47.4 & 5.3 & 0.0 & \multirow[t]{3}{*}{ NS } \\
\hline & $\geq 40$ & 0.0 & 27.6 & 27.6 & 44.8 & 0.0 & 0.0 & \\
\hline & Total & 2.1 & 27.1 & 22.9 & 45.8 & 2.1 & 0.0 & \\
\hline \multirow[t]{3}{*}{ Fruit } & $<40$ & 0.0 & 0.0 & 10.5 & 47.4 & 21.1 & 21.1 & \multirow[t]{3}{*}{ NS } \\
\hline & $\geq 40$ & 0.0 & 0.0 & 13.8 & 37.9 & 24.1 & 24.1 & \\
\hline & Total & 0.0 & 0.0 & 12.5 & 41.7 & 22.9 & 22.9 & \\
\hline Vegetables & $<40$ & 0.0 & 5.3 & 0.0 & 47.4 & 15.8 & 31.6 & NS \\
\hline & $\geq 40$ & 0.0 & 0.0 & 6.9 & 44.8 & 34.5 & 13.8 & \\
\hline & Total & 0.0 & 2.1 & 4.2 & 45.8 & 27.1 & 20.8 & \\
\hline
\end{tabular}

NS - statistically non-significant difference. 
Table 4. The frequency of intake of food products with a potentially adverse effect on health depending on the age of the respondents (\%)

\begin{tabular}{|c|c|c|c|c|c|c|c|c|}
\hline \multirow[t]{2}{*}{ Product } & \multirow{2}{*}{$\begin{array}{c}\text { Age } \\
\text { category } \\
\text { [years] }\end{array}$} & \multicolumn{6}{|c|}{ Frequency of intake (\%) } & \multirow[t]{2}{*}{$P$-value } \\
\hline & & $\begin{array}{c}\text { No } \\
\text { consumption }\end{array}$ & $\begin{array}{c}1-3 \\
\text { times } \\
\text { a week }\end{array}$ & $\begin{array}{c}\text { Once } \\
\text { a week }\end{array}$ & $\begin{array}{l}\text { A few } \\
\text { times } \\
\text { a week }\end{array}$ & $\begin{array}{l}\text { Every } \\
\text { day }\end{array}$ & $\begin{array}{l}\text { A few } \\
\text { times } \\
\text { a day }\end{array}$ & \\
\hline \multirow{3}{*}{$\begin{array}{l}\text { White rice, } \\
\text { pasta, fine } \\
\text { groats }\end{array}$} & $<40$ & 0.0 & 26.3 & 36.8 & 36.8 & 0.0 & 0.0 & \multirow[t]{3}{*}{ NS } \\
\hline & $\geq 40$ & 3.5 & 24.1 & 44.8 & 27.6 & 0.0 & 0.0 & \\
\hline & Total & 2.1 & 25.0 & 41.7 & 31.3 & 0.0 & 0.0 & \\
\hline \multirow[t]{3}{*}{ Fast food } & $<40$ & 10.5 & 89.5 & 0.0 & 0.0 & 0.0 & 0.0 & \multirow[t]{3}{*}{ NS } \\
\hline & $\geq 40$ & 17.2 & 65.5 & 10.3 & 6.9 & 0.0 & 0.0 & \\
\hline & Total & 14.6 & 75.0 & 6.3 & 4.2 & 0.0 & 0.0 & \\
\hline \multirow[t]{3}{*}{ Fried food } & $<40$ & 0.0 & 21.1 & 31.6 & 42.1 & 5.3 & 0.0 & \multirow[t]{3}{*}{ NS } \\
\hline & $\geq 40$ & 3.5 & 44.8 & 13.8 & 37.9 & 0.0 & 0.0 & \\
\hline & Total & 2.1 & 35.4 & 20.8 & 39.6 & 2.1 & 0.0 & \\
\hline \multirow[t]{3}{*}{ Butter } & $<40$ & 5.3 & 26.3 & 15.8 & 10.5 & 26.3 & 15.8 & \multirow[t]{3}{*}{ NS } \\
\hline & $\geq 40$ & 10.3 & 13.8 & 10.3 & 24.1 & 20.7 & 20.7 & \\
\hline & Total & 8.3 & 18.8 & 12.5 & 18.8 & 22.9 & 18.8 & \\
\hline \multirow[t]{3}{*}{ Lard } & $<40$ & 84.2 & 10.5 & 0.0 & 5.3 & 0.0 & 0.0 & \multirow[t]{3}{*}{ NS } \\
\hline & $\geq 40$ & 65.5 & 13.8 & 6.9 & 10.3 & 0.0 & 3.5 & \\
\hline & Total & 72.9 & 12.5 & 4.2 & 8.3 & 0.0 & 2.1 & \\
\hline \multirow{3}{*}{$\begin{array}{l}\text { Hard, processed, } \\
\text { or blue cheeses }\end{array}$} & $<40$ & 0.0 & 36.8 & 26.3 & 36.8 & 0.0 & 0.0 & \multirow[t]{3}{*}{ NS } \\
\hline & $\geq 40$ & 3.5 & 34.5 & 17.2 & 41.4 & 3.5 & 0.0 & \\
\hline & Total & 2.1 & 35.4 & 20.8 & 39.6 & 2.1 & 0.0 & \\
\hline \multirow{3}{*}{$\begin{array}{l}\text { Cold cuts, } \\
\text { sausages, } \\
\text { frankfurters }\end{array}$} & $<40$ & 5.3 & 15.8 & 10.5 & 15.8 & 31.6 & 21.1 & \multirow[t]{3}{*}{$<0.05$} \\
\hline & $\geq 40$ & 0.0 & 3.5 & 20.7 & 51.7 & 10.3 & 13.8 & \\
\hline & Total & 2.1 & 8.3 & 16.7 & 37.5 & 18.8 & 16.7 & \\
\hline \multirow[t]{3}{*}{ Red meat } & $<40$ & 10.5 & 21.1 & 10.5 & 42.1 & 10.5 & 5.3 & \multirow[t]{3}{*}{ NS } \\
\hline & $\geq 40$ & 6.9 & 31.0 & 34.5 & 24.1 & 3.5 & 0.0 & \\
\hline & Total & 8.3 & 27.1 & 25.0 & 31.3 & 6.3 & 2.1 & \\
\hline \multirow[t]{3}{*}{ Sweets } & $<40$ & 0.0 & 31.6 & 21.1 & 21.1 & 21.1 & 5.3 & \multirow[t]{3}{*}{$<0.05$} \\
\hline & $\geq 40$ & 3.5 & 20.7 & 17.2 & 41.4 & 0.0 & 17.2 & \\
\hline & Total & 2.1 & 25.0 & 18.8 & 33.3 & 8.3 & 12.5 & \\
\hline \multirow[t]{3}{*}{ Tinned meat } & $<40$ & 73.7 & 26.3 & 0.0 & 0.0 & 0.0 & 0.0 & \multirow[t]{3}{*}{ NS } \\
\hline & $\geq 40$ & 51.7 & 37.9 & 3.5 & 6.9 & 0.0 & 0.0 & \\
\hline & Total & 60.4 & 33.3 & 2.1 & 4.2 & 0.0 & 0.0 & \\
\hline Carbonated & $<40$ & 10.5 & 52.6 & 21.1 & 5.3 & 0.0 & 10.5 & NS \\
\hline $\begin{array}{l}\text { sweetened } \\
\text { drinks }\end{array}$ & $\geq 40$ & 20.7 & 34.5 & 17.2 & 24.1 & 0.0 & 3.5 & \\
\hline & Total & 16.7 & 41.7 & 18.8 & 16.7 & 0.0 & 6.3 & \\
\hline Energy drinks & $<40$ & 57.9 & 31.6 & 0.0 & 0.0 & 5.3 & 5.3 & NS \\
\hline & $\geq 40$ & 72.4 & 17.2 & 0.0 & 6.9 & 0.0 & 3.5 & \\
\hline & Total & 66.7 & 22.9 & 0.0 & 4.2 & 2.1 & 4.2 & \\
\hline Alcoholic & $<40$ & 26.3 & 63.2 & 10.5 & 0.0 & 0.0 & 0.0 & NS \\
\hline & $\geq 40$ & 41.4 & 44.8 & 10.3 & 3.5 & 0.0 & 0.0 & \\
\hline & Total & 35.4 & 52.1 & 10.4 & 2.1 & 0.0 & 0.0 & \\
\hline
\end{tabular}

NS - statistically non-significant difference. 
on health (wholemeal bread, milk, fermented milk drinks, cottage cheese, fish dishes, legumes, potatoes, fruit, vegetables, canned vegetables, or fruit juices). Approx. $12 \%$ of patients consumed wholemeal bread and/or coarse groats every day. Only $6 \%$ of the respondents drank milk every day, $4 \%$ fermented milk drinks, and 35\% consumed cottage cheese several times a week. Poultry meat was eaten by $63 \%$ of the subjects several times a week, and eggs by about $50 \%$. Approximately $48 \%$ ate fish once a week. As many as $75 \%$ of the patients used legumes in dishes several times a month. Only $20 \%$ of patients ate vegetables several times a day, and about $23 \%$ of them ate fruit. Patients over 40 years of age chose poultry significantly more often (Table 3 ).

Table 4 shows the frequency of consumption of 9 foods with potentially adverse health effects (fast food, meat- and flour-based fried foods, hard cheese and processed cheese, sweets and confectionery, instant and ready-made soups, canned meat, sweetened carbonated drinks, energy drinks, and alcoholic drinks). The highest percentage of subjects $(42 \%$ of the subject group) consumed white rice, pasta, and fine groats at least once a week. Approx. 40\% of patients consumed fried foods several times a week. Fast food was consumed several times a month by $75 \%$ of patients. As a spread for bread, the patients mainly used butter, and almost $20 \%$ of the patients used butter several times a day. Approximately $40 \%$ of the patients ate hard cheese and/or processed cheese several times a week. With the same frequency, 37\% of subjects ate cold cuts, sausages, and frankfurters, and 31\% ate red meat. Additionally, as many as $13 \%$ of patients ate sweets several times a day, $17 \%$ of the subjects drank carbonated sweetened drinks, and over $50 \%$ of patients consumed alcohol several times a month. Patients over 40 years old consumed sweets, cold cuts, sausages, and frankfurters significantly more often than patients under 40 years of age.

Most patients scored low on the 'healthy diet index' (Table 5). Similarly, most patients (including all persons aged $>40$ years) scored low on the 'unhealthy diet index' (approx. 96\% of the subjects). Only 16.7\% of the total number of subjects had good nutritional knowledge while about $77 \%$ - regardless of the obesity class - had sufficient knowledge. It should be noted that none of the patients under the age of 40 years had an insufficient level of nutritional knowledge.

\section{Discussion}

Treatment of obesity is multidirectional and requires the cooperation of many specialists [13]. It consists of introducing lifestyle changes in the form of modifying eating habits through nutritional education and psychotherapy, as well as increasing physical activity $[14,15]$. A properly balanced and varied diet with an energy deficit of varying degree, controlled physical activity, and systematic evaluation of treatment results allow the reduction of body weight and prevention of obesity recurrence after bariatric surgery [15-17].

The recommended number of meals was consumed by $67 \%$ of the participants in this study. Similar results were obtained by Lange et al. [18] and MędrelaKuder [19], who reported that over $60 \%$ of overweight or women with obesity ate more than 3 meals a day. Szczepańska and Brończyk-Puzoń obtained different

Table 5. Distribution of dietary features of patients depending on the age of the subjects (\%)

\begin{tabular}{|c|c|c|c|}
\hline \multirow[t]{3}{*}{ Features } & \multicolumn{2}{|c|}{ Age category } & \multirow{3}{*}{$\begin{array}{c}\text { Total } \\
(n=48)\end{array}$} \\
\hline & $<40$ years & $\geq 40$ years & \\
\hline & $(n=17)$ & $(n=31)$ & \\
\hline \multicolumn{4}{|c|}{ Evaluation of nutritional knowledge: } \\
\hline Insufficient & 0.0 & 10.3 & 6.3 \\
\hline Sufficient & 84.2 & 72.4 & 77.1 \\
\hline Good & 15.8 & 17.2 & 16.7 \\
\hline \multicolumn{4}{|c|}{ Scores on the healthy diet index: } \\
\hline Low & 89.5 & 89.7 & 89.6 \\
\hline Moderate & 10.5 & 10.3 & 10.4 \\
\hline High & 0.0 & 0.0 & 0.0 \\
\hline \multicolumn{4}{|c|}{ Scores on the unhealthy diet index: } \\
\hline Low & 89.5 & 100.0 & 95.8 \\
\hline Moderate & 10.5 & 0.0 & 4.2 \\
\hline High & 0.0 & 0.0 & 0.0 \\
\hline
\end{tabular}


results, in which only $32 \%$ of participants consumed 4-5 meals a day [20]. An inadequate number of meals and long breaks between them deplete glycogen stores in muscles and liver whilst lowering blood glucose levels, resulting in a sharp increase in appetite, especially for high-energy foods.

The analysis of the results of our own research on the frequency of food intake showed that only $1 / 5$ of patients declared the daily consumption of fruit and vegetables in accordance with the current recommendations [21]. Food portions lacking in variety from this group do not ensure sufficient consumption of dietary fibre, minerals, and vitamins [10]. In studies conducted by Szczepańska and Brończyk-Puzoń among women, such a low frequency of intake of vegetables and fruit was declared by over $60 \%$ of respondents [20]. Kaniewska et al. showed that the recommended daily intake of fruit and vegetables was declared by only half of the surveyed men, and in the group of women, $76 \%$ consumed fruit and $83 \%$ consumed vegetables each day [22].

Milk and dairy products are a source of calcium and, among others, branched-chain amino acids, peptides and proteins (whey and casein), which have a beneficial effect on body composition. Calcium influences thermogenesis and lipid metabolism in adipocytes, and contributes to an increase in energy expenditure and a reduction in adipose tissue deposition $[23,24]$. Its adequate consumption is associated with the reduction of the amount of cytosolic calcium in fat cells and the intensification of fatty acid oxidation [25]. Our own study showed that only $6 \%$ of patients consumed milk every day and $4 \%$ drank fermented drinks. Research by Rautiainen et al. indicates that high levels of calcium in the diet can reduce weight gain and prevent obesity in adult women [26]. It has been found that for women, the risk of obesity as measured by various characteristics of body weight and body composition is reduced by $7-11 \%$ for every $100 \mathrm{mg}$ of calcium in the diet. The existence of a positive relationship between a lower level of body fat and higher consumption of dairy products and calcium is confirmed, among others, by DASH studies and the work of Pabjan et al. [27, 28].

In the authors' own research, about $96 \%$ of patients had low scores on the 'unhealthy diet index', and none of the patients had a high score. Thirteen per cent of patients ate sweets several times a day. An additional source of sugar was sweetened carbonated drinks, which $17 \%$ of patients drank several times a week. Research by Kaniewska et al. showed significantly more frequent intake of cake in the group of women compared to the group of men [22]. Sixty percent of women and $36 \%$ of men declared eating cake at least 1-2 times a week. Sweet products, such as sweets and confectionary, are outside the healthy eating pyramid, and their consumption leads, among others, to the development of excess body weight, and increased blood glucose and triglycerides [29-31]. It has been found that, in addition to lipid disorders, eating a diet rich in sugar for just a few weeks causes numerous changes observed as ischaemic heart disease and other vascular diseases [32]. Both human and animal studies indicate various metabolic risks of coronary artery disease when following a diet high in sweets and sugar [33, 34].

Nutrition standards still recommend limiting the consumption of saturated fat [35]. This recommendation is largely based on the observation that eating high-fat meals leads to weight gain, and that saturated fat may increase total serum cholesterol levels, and thus possibly increase the risk of coronary atherosclerosis [30]. The source of this fat is meat and its products, fast food, and sweets. In our own research, $37 \%$ of the subjects ate cold cuts, sausages, and frankfurters, and $31 \%$ ate red meat in their meals several times a week. Fast food was consumed several times a month by as many as $75 \%$ of the subjects. Research by Kaniewska et al. showed that the consumption of fast food among patients differed depending on sex: $60 \%$ of women and $36 \%$ of men did not eat this type of product at all, which is a favourable nutritional behaviour [22]. According to the authors, the risk of obesity increases with the frequency of consumption of this type of food. According to the research by Szczepańska and Brończyk-Puzon, $48 \%$ of patients included fast food in their diet less often than several times a week [20]. Schroder et al. indicated that the value of BMI was closely related to the amount of fast food consumed [33].

\section{Conclusions}

A significant influence of age was observed on the frequency of consumption of poultry, cold cuts, sausages, frankfurters, and sweets. The percentage of patients who had good nutritional knowledge was only $16.7 \%$. The low scores on the healthy diet index indicates the need for regular dietary consultations, during which patients will be educated about the use of food information and the application of healthy eating principles in practice. In order to increase the effectiveness of bariatric treatment, it is necessary to correct nutritional behaviours during the preoperative period, not afterwards.

In a multidisciplinary team of specialists treating obesity, the participation of dietitians is required at the stage of qualifying patients for bariatric surgery.

\section{Acknowledgments}

We would like to thank the people with obesity who participated in the study.

The project was supported under the program of the Minister of Science and Higher Education under the name "Regional Initiative of Excellence" in 20192022, project number: 024/RID/2018/19, financing amount: 11,999,000.00 PLN. 


\section{Conflict of interest}

The authors declare no conflict of interest.

\section{References}

1. Jensen MD, Ryan DH, Apovian CM, Ard J, Comuzzie A Donato K. AHA/ACC/TOS guideline for the management of overweight and obesity in adults: a report of the American College of Cardiology/American Heart Association Task Force on Practice Guidelines, and The Obesity Society. J Am Coll Cardiol 2014; 63: 2985-3023.

2. Raynor HA, Champagne CM. Position of the Academy of Nutrition and Dietetics: interventions for the treatment of overweight and obesity in adults. J Acad Nutr Diet 2016; 116: 129-147.

3. GUS. Zdrowie i ochrona zdrowia w 2017r. https://stat. gov.pl/download/gfx/portalinformacyjny/pl/defaultaktualnosci/5513/1/8/1/zdrowie_i_ochrona_zdrowia_2017. pdf [accessed 12 December 2020].

4. Dobbs R, Sawers C, Thompson F, Manyika J, Woetzel J, Child P, Mckenna S, Spatharou A. Overcoming Obesity: An Initial Economic Analysis. McKinsey Global Institute, New York 2014.

5. Budzyński A, Major P, Głuszek S, Kaseja K, Koszutski T, Leśniak S, Lewandowski T, Lipka M, Lisik W, Makarewicz W, Michalik M, Myśliwiec P, Ostrowska L, Orłowski M, Paluszkiewicz R, Pastuszka M, Paśnik K, Pędziwiatr M, Proczko-Stepaniak M, Hady HR, Rogula T, Smyczek D, Szeliga J, Szewczyk T, Szymański P, Tarnowski W, Wallner G, Wyleżoł M. Polskie rekomendacje w zakresie chirurgii bariatrycznej i metabolicznej [Polish recommendations in the field of bariatric and metabolic surgery]. Med Prakt Chirurgia 2016; 6: 13-25.

6. Kumar S, Kelly AS. Review of childhood obesity: from epidemiology, etiology, and comorbidities to clinical assessment and treatment. Mayo Clin Proc 2017; 92 251-265.

7. Głuszek S, Bociek A, Suliga E, Matykiewicz J, Kołomańska M, Bryk P, et al. The effect of bariatric surgery on weight loss and metabolic changes in adults with obesity. Int J Environ Res Public Health 2020; 17: 5342.

8. Yumuk V, Tsigos C, Fried M, Schindler K, Busetto L, Micic D, Toplak H; Obesity Management Task Force of the European Association for the Study of Obesity. European guidelines for obesity management in adults. Obes Facts 2015; 8: 402-424.

9. Zalecenia PTD, Zalecenia kliniczne dotyczące postępowania u chorych na cukrzycę. [PTD recommendations. Clinical recommendations for the management of diabetes]. Clin. Diabetol 2014; 3: 1-46.

10. Tabesh MR, Maleklou F, Ejtehadi F, Alizadeh Z. Nutrition, physical activity, and prescription of supplements in preand post-bariatric surgery patients: a practical guideline. Obes Surg 2019; 29: 3385-3400.

11. Gibson R. Principles of Nutritional Assessment. Oxford University Press, Oxford 2005.

12. http://www.knozc.pan.pl/images/ Kwestionariusz_KomPAN.pdf [accessed 10 September 2020] Jezewska-Zychowicz M, Gawecki J, Wadolowska L et al. Dietary Habits and Nutrition Beliefs Questionnaire for people 15-65 years old, version 1.2. - self-administered questionnaire. Chapter 2. (in:) Dietary Habits and Nutrition Beliefs Questionnaire and the manual for developing of nutritional data. Ed. Gawecki J. The Committee of Human Nutrition, Polish Academy of Sciences, Olsztyn, 2018, 21-33.

13. Cambi MPC, Baretta GAP. Bariatric diet guide: plate model template for bariatric surgery patients ABCD Arq Bras Cir Dig 2018; 31: 1375-1379.

14. Delgado Floody P, Caamaño Navarrete F, Jerez Mayorga D, Campos Jara C, Campillo RR, Poblete AO, Hormazabal MA, Lepeley NT, Mansilla yCS. Effects of a multidisciplinary program on morbid obese patients and patients with comorbility who are likely to be candidates for bariatric surgery. Nutr Hosp 2015; 31: 2011-2016.

15. Tack J. Complications of bariatric surgery: dumping syndrome, reflux and vitamin deficiencies. Best Pract Res Clin Gastroenterol 2014; 28: 741-749.

16. Podgórska L, Paśnik K. Rola dietetyka w prowadzeniu chorego leczonego bariatrycznie [The role of a dietitian in managing a patient treated bariatrically]. Piel Zdr Publ 2014; 4: 277-283.

17. Ashtary-Larky D, Ghanavati M, Lamuchi-Deli N, Payami S, Alavi-Rad S, Boustaninejad M, Afrisham R, Abbasnezhad A, Meysam A. Rapid weight loss vs. slow weight loss: which is more effective on body composition and metabolic risk factors? Int J Endocrinol Metab 2017; 15: e13249.

18. Lange E, Krusiec J, Kulik A. Wybrane zachowania żywieniowe kobiet i mężczyzn $\mathrm{z}$ nadmierną masa ciała [Selected nutritional behaviors of overweight women and men]. Prob Hig Epidemiol 2011; 92: 580-582.

19. Mędrela-Kuder E. Wybrane zwyczaje żywieniowe w grupie kobiet $\mathrm{z}$ nadwagą lub otyłością [Some nutritional habits of a group of overweight and woman with obesity]. Rocz Panstw Zakl Hig 2005; 56: 371-377.

20. Szczepańska E, Brończyk-Puzoń A. Ocena nawyków żywieniowych pacjentów z otyłością, zakwalifikowanych do zabiegu bariatrycznego [Evaluation of nutritional habits of patients with obesity qualified for bariatric surgery]. Med Ogólna Nauk Zdr 2014; 20: 330-334.

21. Zalecenia zdrowego żywienia. [Recommendations of healthy eating]. Narodowy Instytut Zdrowia Publicznego, 2020. Available at: https://ncez.pl/upload/talerz-i-zalecenia.pdf [accessed 20 December 2020].

22. Kaniewska E, Gaździńska A, Jagielski P, Gaździński S. Wyleżoł M. Ocena częstotliwości spożycia wybranych produktów spożywczych przez chorych zakwalifikowanych do zabiegowego leczenia otyłości [Assessment of selected food intake frequency in patients with obesity qualified for bariatric surgery]. Hygeia Public Health 2016; 51: 66-70.

23. Dugan CE, Fernandez ML. Effects of dairy on metabolic syndrome parameters: a review. Yale J Biol Med 2014; 87: 135-147.

24. Lee HJ, Cho JI, Lee HS, Kim Ch, Choet E. Intakes of dairy products and calcium and obesity in Korean adults: Korean national health and nutrition examination surveys (KNHANES) 2007-2009. PLoS One 2014; 9: 6.

25. Skowronska-Jóźwiak E, Jaworski M, Lorenc R, KarbownikLewinska M, Lewinski A. Niskie spożycie wapnia w produktach mlecznych jest związane z nadwagą i podwyższonym ciśnieniem krwi u dorosłych Polaków, zwłaszcza $\mathrm{u}$ kobiet przed menopauzą [Low calcium intake in dairy products is associated with overweight and elevated blood pressure in adult Poles, especially in premenopausal women]. Zdrowie Publiczne 2016; 20: 630-637. 
26. Rautiainen S, Wang L, Lee IM, Manson JE, Buring JE, Sesso HD. Dairy consumption in association with weight change and risk of becoming overweight or obese in middle-aged and older women: a prospective cohort study. J Clin Nutr 2016; 103: 979-988.

27. NIH, U.S. Department of Health and Human Services, National Institutes of Health, National Heart, Lung, and Blood Institute, Your guide to lowering your blood pressure with DASH. DASH eating plan. NIH Publication No. 06- 4082, 2006.

28. Pabjan K, Wądołowska L, Słowińska MA, Czlapka-Matyasik M, Niedzwiedzka E. Body composition of motherdaughter family pairs in relation to dairy products and calcium intake. Pol J Food Nutr Sci 2010; 60: 77-88.

29. Murphy MM, Barraj LM, Bi X, Stettler N. Body weight status and cardiovascular risk factors in adults by frequency of candy consumption. Nutr J 2013; 12: 53-64.

30. Yu E, Malik V, Hu F. Cardiovascular disease prevention by diet modification. JACC 2018; 72: 2951-2963.

31. Biskup M, Macek P, Król H, Kowalik A, Madej Ł, Zak M, Gózdz S. The role of the rs1421085 polymorphism in the pathogenesis of obesity. Medica Studies 2020; 36: 110-115.

32. Anand S, Hawkes C, de Souza R. Food consumption and its impact on cardiovascular disease: importance of solutions focused on the globalized food system. J Am Coll Cardiol 2015; 66: 1590-1614.

33. Schröder H, Fito M, Covas MI. Association of fast food consumption with energy intake, diet quality, body mass index and the risk of obesity in a representative Mediterranean population. Br J Nutr 2007; 98: 1274-1280.

34. Sivakumar J, Chong L, Ward S, Sutherland T, Read M, Hii M. Body Composition changes following a very-low-calorie pre-operative diet in patients undergoing bariatric surgery. Obes Surg 2020; 30: 119-126.

35. Jarosz M, Rychlik E, Stoś K. Charzewska J. Normy żywienia dla populacji Polski i ich zastosowanie [Nutrition standards for the Polish population and their application]. Available at: https://ncez.pl/abc-zywienia-/zasady-zdrowego-zywienia/normy-zywienia-2020 [accessed 20 December 2020].

\section{Address for correspondence:}

\section{Kamila Sobaś}

Institute of Health Sciences

Medical College

Jan Kochanowski University

25-369 Kielce, Poland

E-mail: kamila.sobas@ujk.edu.pl 